\title{
Development of a zero trans margarine from soybean-based interesterified fats formulated using artificial neural networks
}

\author{
By R.K.A. Garcia ${ }^{a} \bowtie$, K. Moreira Gandra ${ }^{a}$ and D. Barrera-Arellano ${ }^{a}$ \\ ${ }^{\text {a }}$ Food Technology Department, Faculty of Food Engineering, University of Campinas - UNICAMP, \\ P. O. 6041, 13083-970, Campinas, SP, Brazil \\ Corresponding author: rita@ fea.unicamp.br
}

\section{RESUMEN}

\begin{abstract}
Desarrollo de margarina cero trans formulada a partir de grasa de soja interesterificada, utilizando una red neuronal artificial
\end{abstract}

La formulación de productos con bajos niveles de ácidos grasos trans y saturados es el nuevo desafío para la indutria grasa, y nuevas materias primas alternativas están siendo estudiadas. Las redes neuronales artificiales (RNA) están siendo usadas para este proceso. El objectivo de este estudio fue formular mezclas para margarinas con la ayuda de una RNA, usando grasas interesterificadas de soja para producir margarinas cero trans con funcionalidad similar a las margarinas producidas comercialmente. El software fue entrenado con tres materias primas distintas para generar formulaciones con contenido de grasa solida (CGS) y punto de fusión (PF) similar al de grasas comerciales específicas. El CGS, PF, la composición en ácidos grasos y triglicéridos fueron determinadas para todas las formulaciones de la RNA y de las grasas comerciales. Las margarinas fueron producidas en planta piloto y se evaluó la consistencia y estabilidad por ciclización de temperatura. La RNA fue eficiente en predecir los CGS y PF de las fomulaciones sugeridas por ella, aunque hubo diferencias a bajas temperaturas para el CGS deseado. Se observaron diferencias en consistencia entre las grasas comerciales y mezclas de la RNA, sin embargo, las margarinas producidas en planta piloto mostraron una consistencia similar. La margarina producida con la formulación de la RNA presentó mayor estabilidad de emulsión. En general, la margarina producida con la formulación de la RNA tiene características muy similares a la margarina preparada con la grasa comercial, además las margarinas con grasa a base de soja contenía niveles reducidos de grasa trans y saturada.

PALABRAS CLAVE: Contenido de grasa solida - Grasas interesterificadas - Punto de fusión - Redes neuronales.

\section{SUMMARY}

Development of a zero trans margarine from soybeanbased interesterified fats formulated using artificial neural networks

The formulation of products with low levels of saturated and trans fatty acids is a new challenge for industries, and alternative raw materials have been studied. Artificial neural networks (ANNs) have been used for this process. The objective of the present study was to formulate blends, with the help of an ANN, using soybean-based interesterified fats for the production of a zero trans fat margarine similar to a margarine produced using a specific commercial fat. The software was trained with three raw materials to generate formulations with a solid fat content (SFC) and a melting point (MP) similar to specific commercial fats. The SFC, MP, fatty acid and triacylglycerol composition were determined for all ANN blends and commercial fats. Margarines were produced in a pilot plant and evaluated for consistency and stability under temperature cyclization. The ANN showed efficiency in to predict SFC and MP of the suggested formulations, although there were differences at low temperatures for the desired SFC. Differences in the consistency of the commercial fats and ANN blends were observed; however, the margarines produced in the pilot plant had a similar consistency. The margarine prepared with ANN formulation had a higher emulsion stability. Overall, the margarine produced with ANN formulation had characteristics very similar to margarine produced with the commercial fat, and the margarine with soybean-based fat contained reduced saturated and trans fat levels.

KEY-WORDS: Interesterified fats - Melting point - Neural networks - Solid fat content.

\section{INTRODUCTION}

Evidences of the harmful effects of trans fatty acids (TFA) on human health has led the food industry to seek alternatives for production of transfree products. The demand for trans-free fats has encouraged research into different raw materials and processes for the production of fat for varied purposes. However, although many of the currently used raw materials do not contain trans fatty acids, 
they do contain high amounts of saturated fatty acids. Saturated fatty acids are also considered unhealthy because they contribute to an increased risk of cardiovascular disease (Keys et al., 1965; Mensink et al., 2003).

Interesterified fats are an alternative to produce low trans products because interesterification produces desirable physical changes in the fats without the production of trans isomers (Ribeiro et al., 2007). Despite this advantage, interesterified fats may suffer from limitations due to the difficulty of achieving the same performance as trans fats.

For a fat to achieve the desired characteristics for use in certain products, blends of oils and fats from different sources is often needed. When mixed in the appropriate proportions, a fat exhibiting the specific necessary characteristics is produced. This is the basis for how fats are prepared using various raw materials worldwide. For products in which a hard consistency is required, palm-based fats are usually employed. Palm-based fats contain a high content of saturated fatty acids, and they are not readily available in Brazil; this limitation increases the cost of products that utilize them. In contrast, soybean-based fats and soybean oil are highly available in the Brazilian market. If soybean-based fats are used as the majority of the raw materials, the cost of the products is significantly reduced. In addition, their use results in healthier fatty foods, with a low saturated fat and high polyunsaturated fat content.

The formulation systems of fats in the food industry are normally based on the experience of the formulator. Conventional methods require multiple trial-and-error procedures, which may result in economic losses and consume considerable time and raw materials (Block et al., 1997). Artificial neural networks (ANN) are computational techniques to develop a mathematical model based on the neural structure of intelligent organisms and acquired knowledge through experience (Britto, 1994). The use of ANN as an alternative to conventional methods for the formulation of specialty fats has been previously demonstrated. Block et al. (1997) formulated specialty fats from hydrogenated fats and refined soybean oil using an ANN, and they developed a computer program specifically for this purpose: Software Mix (BarreraArellano et al., 2005). ANN were highly efficient for the development of margarines produced from hydrogenated fats in a pilot plant, demonstrating that ANN may be used to formulate products with the same characteristics as those formulated using conventional methods (Block et al., 1999; Block et al., 2003).

The use of ANN trained with soybean-based interesterified fats may allow for the formulation of trans-free products similar to commercial products that are currently formulated using blends of fats from sources that are frequently costly in Brazil. Starting from the desired profile, the ANN used in this study proposes various formulations that consist of different amounts of raw materials, and allows the user to choose the formulations of interest. Thus, it becomes possible to choose formulations with reduced quantities of saturated and trans fatty acids, as well as higher quantities of polyunsaturates.

The aim of this study was to develop a low-trans hard margarine using soybean fats and soybean oil (sources available in the Brazilian market). Furthermore, an ANN was used to formulate these products.

\section{MATERIALS AND METHODS}

\subsection{Material}

Two soybean-based interesterified fats, Fat A (soybean/palm kernel) with a MP of $53^{\circ} \mathrm{C}$ and Fat $\mathrm{B}$ (soybean/cottonseed/palm kernel) with a MP of $47.3^{\circ} \mathrm{C}$, provided by Triângulo Alimentos (Itápolis, $\mathrm{SP}$, Brazil), and a commercial refined soybean oil, were used for training the ANN and preparing the blends. Commercial fats for hard margarines were used as the standard fats: a zero-trans fat (Standard fat 1) and a high-trans fat (Standard fat 2) provided by Triângulo Alimentos (Itápolis, SP, Brazil) and Bunge Alimentos (Gaspar, SC, Brazil), respectively.

\subsection{Methods}

\subsubsection{Fatty Acid (FA) composition}

Esterification was carried out according to the method of Hartman and Lago (1973), and the fatty acid methyl esters were separated according to the AOCS method Ce 1-62 (AOCS, 2004) using a DB - Agilent, (Agilent, Santa Clara, United States) 23 capillary column (50\% cyanopropyl-methylpolysiloxane), 60 $\mathrm{m}$ in length, $0.25 \mathrm{~mm}$ internal diameter, and 0.25 $\mu \mathrm{m}$ film. The analyses were performed using an Agilent 6850 Series GC system equipped with a capillary column and a flame ionization detector (FID). The oven temperature program was a 5 min hold at $110^{\circ} \mathrm{C}$, increasing from 110 to $215^{\circ} \mathrm{C}$ at a rate of $5^{\circ} \mathrm{C} \cdot \mathrm{min}^{-1}$, and a hold for $24 \mathrm{~min}$ at $215^{\circ} \mathrm{C}$. The detector temperature was $280^{\circ} \mathrm{C}$, the injector temperature was $250^{\circ} \mathrm{C}$, the carrier gas was helium, the split ratio was 1:50, and the injection volume was $1.0 \mathrm{~mL}$. The qualitative composition was determined by comparing the peak retention times with those of fatty acid standards. All samples were analyzed in duplicate.

\subsubsection{Triacylglycerol (TAG) composition}

The TAG compositions were determined according to method Ce 5b-89 (AOCS, 2004) using capillary column gas chromatography (CGC Agilent 6850 series GC system). We used a DB$17 \mathrm{HT}$ (50\% phenyl-methylpolysiloxane) capillary column, $15 \mathrm{~m}$ in length, $0.25 \mathrm{~mm}$ internal diameter, and $0.15 \mu \mathrm{m}$ film. The column temperature was 
$250^{\circ} \mathrm{C}$, increased up to $350^{\circ} \mathrm{C}$ at $5^{\circ} \mathrm{C} \cdot \mathrm{min}^{-1}$, $1: 30$ split injection ratio, helium carrier gas at 1.0 $\mathrm{mL} \cdot \mathrm{min}^{-1}$ flow rate, $360^{\circ} \mathrm{C}$ injector temperature, $375^{\circ} \mathrm{C}$ detector temperature, $1.0 \mu \mathrm{L}$ injection volume, and $100 \mathrm{mg} \cdot 5 \mathrm{~mL}^{-1}$ in tetrahydrofuran sample concentration. TAG identification was carried out by comparing retention times according to the methods of Antoniossi Filho et al. (1995). All samples were analyzed in duplicate.

\subsubsection{Iodine index and saponification index}

The iodine and saponification values were calculated from the fatty acid composition according to methods $\mathrm{Cd} 1 \mathrm{c}-85$ and $\mathrm{Cd} 31-94$, respectively (AOCS, 2004).

\subsubsection{Solid fat content (SFC)}

The SFC was determined according to method Cd 16b-93 (AOCS, 2004) using nuclear magnetic resonance (NMR). A Bruker PC120 Minispec spectrometer (Bruker, Bremen, Germany) was used to read samples in series at $15,20,25,30$, $35,37.5$, and $40^{\circ} \mathrm{C}$, and samples were analyzed in duplicate.

\subsubsection{Melting point (MP)}

The MPs were determined according to method Cc 18-80 (AOCS, 2004) using a Mettler FP90 Control Unit (Mettler, Pasadena, Maryland, United States), and samples were analyzed in triplicate.

\subsubsection{Consistency}

Margarine samples were tested for consistency using the penetration test with an acrylic cone with an apex angle of $40^{\circ}$ and no truncation in a TA-XT2i texture analyzer (Stable Micro Systems, Haslemere, United Kingdon) according to Ribeiro et al. (2009). The penetration data were converted to calculate the yield value (Haighton, 1959). Data were obtained at $10,20,25,30,35$, and $40^{\circ} \mathrm{C}$. All samples were tested in triplicate, and the means were used to calculate the yield value.

\subsubsection{Margarine Emulsion Stability}

Emulsion stabilities were measured in triplicate with two temperature cyclization steps using the industry methodology (Danisco, Cotia, São Paulo, Brazil). In the first step, the samples remained at $5^{\circ} \mathrm{C}$ for $48 \mathrm{~h}$ to allow for full complete crystallization. They were then placed at $35^{\circ} \mathrm{C}$ for $24 \mathrm{~h}$ and immediately tested. The samples were placed in a cooling temperature for another $24 \mathrm{~h}$ and tested again. In the second step, the samples were stored at $35^{\circ} \mathrm{C}$ for $48 \mathrm{~h}$, analyzed, cooled (to $5-10^{\circ} \mathrm{C}$ ) for an additional $72 \mathrm{~h}$, and tested again.

\subsubsection{Statistics}

To detect significant differences, we applied Tukey's test $(p<0.05)$ using Statistica $₫ 7.0$ software (Statsoft, United States).

\subsection{Experimental Procedure}

\subsubsection{Formulation Process by ANN}

The ANN used in the present study was a multilayer perceptron with sigmoid-type activation functions. It consisted of an input layer with three variables representing a blend of the example formulations (a percentage of each raw material), two intermediate layers containing 15 neurons each, and an output layer that consisted of eight variables representing the SFC at seven different temperatures and the MPs of the example formulations.

The fat blends for margarine were formulated using the ANN trained by Gandra et al. (2009), using soybean oil and two soybean-based interesterified fats with different MPs, using the Software Mix (Barrera-Arellano et al., 2005). During training, 62 blends were formulated with different proportions of the three raw materials. The input data utilized was the SFC and the MP of each formulation, as well as the proportion of each raw material, according to Block et al. (1997).

Raw materials (interesterified fats $A, B$, and oil) and commercial fats (1 and 2) were characterized for SFC at $10,20,25,30,35,37.5$, and $45^{\circ} \mathrm{C}$, as well as for their MP, their fatty acid composition, and their triacylglycerol composition. After supplying the data to the software Mix (the SFC and MP of the commercial fats were used as the standards for margarine fats) the search for mixtures (containing different proportions of the three raw materials) with similar SFC and MP values was performed. Of the proposed formulations for each commercial fat, three formulations with SFC and MP values close to the desired values were selected.

The blends suggested by the ANN for each commercial fat were formulated and analyzed for SFC, MP, fatty acid composition, and triacylglycerol composition. The consistency of the commercial fats and the ANN blends were determined and compared. To test the effectiveness of the ANN formulations under real processing conditions, a commercial fat and a formulation proposed by the ANN with similar profiles were selected for production in a pilot plant. The margarines were analyzed for consistency and stability by temperature cyclization.

\subsubsection{Margarine Production}

Margarines were prepared at Danisco's (Cotia, SP, Brazil) pilot plant using the model Perfector $(1+1)$ X 57 (Gerstenberg \& Agger A/S, Conpenhagen, Denmark) encompassing an $8 \mathrm{~kg}$ capacity emulsion tank, two cooling units (crystallizers), and intermediate 
pin units for mechanical work. The margarines were produced under the same conditions, using the same ingredients and additives, and standardized to $67 \%$ fat content according to the base formulation suggested by Danisco: $31 \%$ water, $1.5 \%$ sodium chloride, $0.05 \%$ sodium benzoate, $0.05 \%$ potassium sorbate, $0.10 \%$ powdered skim milk, 0.6\% Dimodan $®$ UP/B (Danisco, Cotia, São Paulo, Brazil), 0.003\% beta-carotene (FMC Química do Brasil Ltda, Campinas, São Paulo, Brazil), 0.04\% butter flavor (Kerry, Campinas, São Paulo, Brazil), and $0.03 \%$ Grindox ${ }^{\mathrm{TM}} 204$ antioxidant (Danisco, Cotia, São Paulo, Brazil).

\section{RESULTS AND DISCUSSION}

The fatty acid composition of the raw materials and commercial samples is shown in Table 1. Raw materials $A$ and $B$ had compositions characteristic of soybean products. Commercial fat 1 is likely to be a palm fat or palm oil-based fat due to the levels of palmitic and oleic acids it contained. The fatty acid composition of commercial fat 2 indicated the use of partially hydrogenated fats due to high levels
(11.28\%) of trans isomers. Palmitic and lauric acid values also indicated the presence of palm fat and palm kernel oil.

According to the TAG composition (Table 2), interesterified fats $A$ and $B$ had TAG values similar to those measured by Ribeiro et al. (2009) and were characteristic of soybean-based fats, and the soybean oil also had the expected values. The TAG values for the commercial fats are presented in Table 2.

The formulations proposed by the ANN are listed in Table 3 (the proportions of each raw material). The SFC of the interesterified fats $A$ and $B$ used for training the ANN are listed in Table 4, as are the SFC and MP of each commercial fat and the blends suggested by ANN.

Fats 1 and 2 had high SFC and MP, which are characteristic of fats used in cooking or industrial margarines (Hoffmam, 1989). After to solicit responses (ANN formulations) with SFC similar to the commercial fats, the SFC values predicted for each formulation were experimentally tested. The values showed major differences at 10 and $45^{\circ} \mathrm{C}$ and minor differences

Table 1

Fatty acid composition $\%$ of raw materials and commercial fats

\begin{tabular}{|c|c|c|c|c|c|}
\hline Fatty Acid & Fat $A^{*}$ & Fat $B^{\star \star}$ & Soybean Oil & $\begin{array}{c}\text { Commercial } \\
\text { Fat } 1\end{array}$ & $\begin{array}{c}\text { Commercial } \\
\text { Fat } 2\end{array}$ \\
\hline C6:0 & - & - & - & 0.02 & - \\
\hline C8:0 & 0.19 & 0.09 & - & 0.24 & 0.18 \\
\hline C10:0 & 0.19 & 0.08 & - & 0.24 & 0.18 \\
\hline C12:0 & 2.36 & 0.77 & - & 3.46 & 2.58 \\
\hline C14:0 & 1.20 & 0.40 & 0.07 & 1.95 & 1.56 \\
\hline C16:0 & 15.77 & 11.64 & 10.05 & 33.28 & 32.66 \\
\hline C16:1 & 0.18 & 0.08 & 0.10 & 0.13 & 0.15 \\
\hline C17:0 & 0.15 & 0.13 & 0.10 & 0.09 & 0.10 \\
\hline C18:0 & 46.06 & 29.46 & 3.86 & 9.24 & 9.00 \\
\hline C18:1 & 1.07 & 0.65 & - & 1.30 & 9.78 \\
\hline C18:1 & 9.20 & 17.40 & 21.14 & 33.06 & 24.54 \\
\hline C18:2 & 0.19 & 0.61 & 0.19 & 0.38 & 1.33 \\
\hline C18:2 & 22.32 & 34.00 & 55.35 & 14.61 & 16.80 \\
\hline C18:3 & - & - & 0.55 & 0.16 & 0.17 \\
\hline C18:3 & 0.17 & 3.40 & 7.55 & 0.94 & 0.16 \\
\hline C20:0 & 0.49 & 0.49 & 0.35 & 0.41 & 0.36 \\
\hline C20:1 & - & 0.15 & 0.16 & 0.15 & 0.08 \\
\hline Saturated & 66.87 & 43.71 & 14.96 & 49.26 & 46.98 \\
\hline Monounsaturated & 9.38 & 17.63 & 21.4 & 33.36 & 24.79 \\
\hline Polyunsaturated & 22.49 & 37.4 & 62.9 & 15.54 & 16.96 \\
\hline Total trans & 1.26 & 1.26 & 0.74 & 1.84 & 11.28 \\
\hline Saponification index & 196.91 & 195.12 & 193.94 & 202.86 & 223.41 \\
\hline lodine index & 47.2 & 82.9 & 134.0 & 49.26 & 50.8 \\
\hline
\end{tabular}

${ }^{\star}$ Fat $A=$ Interesterified fat $A,{ }^{* *}$ Fat $B=$ Interesterified $B$ 
Table 2

Triacylglycerol (TAG) compositions of raw material and commercial fats

\begin{tabular}{|c|c|c|c|c|c|c|}
\hline $\begin{array}{l}\text { Carbon } \\
\text { Number }\end{array}$ & TAG* $\left.^{*} \%\right)$ & $\begin{array}{c}\text { Inter. Fat } \\
\text { A }\end{array}$ & $\begin{array}{c}\text { Inter. Fat } \\
\text { B }\end{array}$ & Soybean Oil & $\begin{array}{c}\text { Commercial } \\
\text { Fat } 1\end{array}$ & Commercial Fat 2 \\
\hline \multirow[t]{2}{*}{ C42 } & LaMP & 0.79 & - & - & - & - \\
\hline & LaOLa & 0.28 & - & - & - & - \\
\hline \multirow[t]{3}{*}{ C44 } & MMP & & & & 2.94 & - \\
\hline & LaPP & 0.56 & - & - & - & - \\
\hline & LaOM & 0.34 & - & - & - & - \\
\hline \multirow[t]{3}{*}{ C46 } & LaPSt & 0.72 & 0.33 & - & 4.35 & 1.66 \\
\hline & LaOP & 0.43 & 0.30 & - & - & 2.17 \\
\hline & LaLP & 0.48 & 0.39 & - & 3.48 & 2.04 \\
\hline \multirow[t]{5}{*}{ C48 } & PPP & 1.69 & 0.51 & - & 4.22 & 7.89 \\
\hline & MOP & 0.52 & 0.35 & - & 2.48 & - \\
\hline & LaOSt & - & - & - & - & 1.29 \\
\hline & MLP & 0.92 & - & - & - & - \\
\hline & LaOO & - & - & - & 5.91 & 1.58 \\
\hline \multirow[t]{3}{*}{ C50 } & PPSt & 5.08 & 1.91 & - & 8.34 & 3.43 \\
\hline & POP & 2.04 & 1.77 & 0.92 & - & 10.89 \\
\hline & PLP & 3.05 & 2.46 & 2.83 & 6.28 & 10.83 \\
\hline \multirow[t]{7}{*}{ C52 } & PStSt & 11.97 & 4.91 & - & 3.52 & 2.22 \\
\hline & POSt & 4.69 & 4.36 & 0.66 & 4.09 & 4.24 \\
\hline & POO & 0.98 & 1.68 & 3.41 & 8.37 & 12.14 \\
\hline & PLSt & 11.67 & 8.50 & 1.73 & - & - \\
\hline & PLO & 2.68 & 5.61 & 10.56 & 6.24 & 9.22 \\
\hline & PLL & 3.33 & 6.35 & 15.15 & 6.63 & 4.75 \\
\hline & PLnL & - & - & 3.15 & - & 0.75 \\
\hline \multirow[t]{12}{*}{ C54 } & StStSt & 10.57 & 4.80 & - & 1.63 & - \\
\hline & StOSt & 5.50 & 4.48 & - & 4.75 & 6.23 \\
\hline & StOO & 0.83 & 1.67 & 0.77 & - & - \\
\hline & StLSt & 14.82 & 10.55 & - & - & - \\
\hline & O०० & - & - & 3.29 & 3.03 & 10.93 \\
\hline & StLO & 4.97 & 8.92 & 2.72 & 6.24 & 2.88 \\
\hline & OLO & - & 3.14 & 12.19 & 5.79 & 1.62 \\
\hline & StLL & 7.17 & 10.43 & - & - & - \\
\hline & OLL & 1.62 & 7.24 & 17.62 & 6.00 & 0.42 \\
\hline & LLL & 2.30 & 7.34 & 19.98 & 1.2 & - \\
\hline & LLnL & - & 2.00 & 5.02 & - & - \\
\hline & Other & - & - & - & 4.51 & 2.92 \\
\hline
\end{tabular}

* $\mathrm{La}=$ lauric acid; $\mathrm{M}=$ myristic acid, $\mathrm{P}=$ palmitic acid, $\mathrm{St}=$ stearic acid, $\mathrm{O}=$ oleic acid, $\mathrm{L}=$ linoleic acid, $\mathrm{L} n=$ linolenic acid. -: not detected.

between 25 and $35^{\circ} \mathrm{C}$ from the predicted SFC. The correlation between the predicted and desired SFC values resulted in coefficients of determination $\left(R^{2}\right)$ between 0.87 and 0.91 for the ANN formulations and the commercial fat 1 , and $\mathrm{R}^{2}$ between 0.90 and 0.92 for commercial fat 2 and the ANN formulations.

The SFC and MP values predicted by the ANN for the proposed formulations were similar to the 
Table 3

Formulations proposed by the neural network from the commercial fats profile

\begin{tabular}{|c|c|c|c|}
\hline \multicolumn{4}{|c|}{ Comercial Fat 1} \\
\hline \multirow{2}{*}{ Solutions } & \multicolumn{3}{|c|}{ Formulations (\%) } \\
\hline & Interesterified Fat A & Interesterified Fat B & Soybean Oil \\
\hline $1 \mathrm{~B}$ & 14.96 & 50.51 & 34.53 \\
\hline $1 \mathrm{C}$ & 9.7 & 45.14 & 45.16 \\
\hline \multicolumn{4}{|c|}{ Comercial Fat 2} \\
\hline \multirow{2}{*}{ Solutions } & \multicolumn{3}{|c|}{ Formulations (\%) } \\
\hline & Interesterified Fat A & Interesterified Fat B & Soybean Oil \\
\hline $2 \mathrm{~A}$ & 39.89 & 48.68 & 11.43 \\
\hline $2 \mathrm{~B}$ & 31.32 & 64.15 & 4.53 \\
\hline $2 \mathrm{C}$ & 35.48 & 54.81 & 9.71 \\
\hline
\end{tabular}

Table 4

Neural network formulations proposed for a commercial bases for hard margarines

\begin{tabular}{|c|c|c|c|c|c|c|c|c|c|}
\hline \multirow{2}{*}{\multicolumn{2}{|c|}{ Raw Materials }} & \multicolumn{8}{|c|}{ SFC (\%) } \\
\hline & & $10^{\circ} \mathrm{C}$ & $20^{\circ} \mathrm{C}$ & $25^{\circ} \mathrm{C}$ & $30^{\circ} \mathrm{C}$ & $35^{\circ} \mathrm{C}$ & $37.5^{\circ} \mathrm{C}$ & $45^{\circ} \mathrm{C}$ & $\operatorname{MP}\left({ }^{\circ} \mathrm{C}\right)$ \\
\hline \multicolumn{2}{|c|}{ Interesterified fat A } & 64.41 & 56.84 & 55.30 & 44.60 & 34.06 & 29.74 & 16.86 & 53.05 \\
\hline \multicolumn{2}{|c|}{ Interesterified B } & 24.48 & 22.10 & 21.63 & 15.26 & 10.53 & 8.06 & 4.05 & 47,35 \\
\hline \multicolumn{2}{|l|}{ Soybean oil } & 0.00 & 0.00 & 0.00 & 0.00 & 0.00 & 0.00 & 0.00 & 0.00 \\
\hline \multicolumn{2}{|c|}{$\begin{array}{l}\text { Commercial fat } 1 \\
\text { (desired SFC and MP)* }^{*}\end{array}$} & 43.47 & 27.18 & 19.35 & 12.44 & 7.34 & 5.02 & 00.00 & 39.00 \\
\hline Solution A & $(\mathrm{P})$ & 21.36 & 20.35 & 17.50 & 12.63 & 09.12 & 7.05 & 03.48 & 46.99 \\
\hline Solution A & $(\mathrm{E})$ & 20.27 & 19.30 & 18.34 & 12.55 & 08.89 & 07.16 & 03.07 & 44.10 \\
\hline Solution B & $(\mathrm{P})$ & 20.47 & 19.26 & 15.64 & 11.61 & 08.60 & 06.67 & 03.31 & 46.39 \\
\hline Solution B & (E) & 19.71 & 19.16 & 16.01 & 11.78 & 08.41 & 06.92 & 03.13 & 44.51 \\
\hline Solution C & $(\mathrm{P})$ & 15.73 & 14.44 & 11.50 & 08.58 & 06.30 & 04.94 & 02.41 & 45.39 \\
\hline Solution C & (E) & 15.63 & 14.79 & 11.63 & 08.50 & 06.11 & 04.89 & 02.41 & 43.10 \\
\hline \multicolumn{2}{|c|}{$\begin{array}{l}\text { Commercial fat } 2 \\
\text { (desired SFC and MP)* }\end{array}$} & 63.81 & 43.56 & 32.63 & 22.24 & 13.84 & 10.02 & 00.39 & 43.00 \\
\hline Solution A & $(P)$ & 37.19 & 34.49 & 30.51 & 23.25 & 17.28 & 14.08 & 07.08 & 49.70 \\
\hline Solution A & $(E)$ & 36.40 & 34.55 & 31.00 & 23.98 & 17.71 & 15.11 & 07.57 & 47.90 \\
\hline Solution B & $(P)$ & 34.83 & 32.19 & 29.71 & 22.18 & 16.25 & 13.17 & 06.58 & 49.47 \\
\hline Solution B & $(E)$ & 35.22 & 31.39 & 30.18 & 23.26 & 16.93 & 14.45 & 07.00 & 47.53 \\
\hline Solution C & $(P)$ & 35.28 & 32.78 & 29.25 & 22.08 & 16.33 & 13.23 & 06.62 & 49.46 \\
\hline Solution C & (E) & 34.97 & 31.87 & 29.95 & 23.20 & 16.73 & 14.49 & 06.88 & 47.23 \\
\hline
\end{tabular}

*(P) Predictes values by neural network, (E) Experimental values

values obtained experimentally; these results are acceptable because the industry works within a range of variation of up to $4^{\circ} \mathrm{C}$. The correlation between the predicted and experimentally values for all formulations proposed by the ANN were R2 > 0.99 at a significance level of $5 \%$.

Table 5 lists the FA and TAG compositions of the formulations proposed by ANN. There was a prevalence of oleic acid and linoleic acid, which are abundant in soybean fats, and stearic acid, which is characteristic of soybean products interesterified with fully hydrogenated soybean oil. Palmitic acid, which largely determines fat plasticity, was also prevalent in the blend compositions. Palmitic acid is also responsible for crystallization in the $\beta$ ' form, an essential characteristic in most products, especially margarines (Jeyarani and Reddy, 2003). 
Table 5

TAG composition and majority fatty acids (FA) of the formulations proposed by the neural network

\begin{tabular}{|c|c|c|c|c|c|c|c|}
\hline Carbon Number & TAG (\%) & $1 \mathrm{~A}$ & 1B & $1 \mathrm{C}$ & $2^{\mathrm{a}}$ & 2B & $2 \mathrm{C}$ \\
\hline \multirow[t]{2}{*}{ C42 } & LaMP & 0.07 & 0.12 & 0.08 & 0.32 & 0.25 & 0.28 \\
\hline & LaOLa & 0.02 & 0.04 & 0.03 & 0.11 & 0.09 & 0.10 \\
\hline \multirow[t]{2}{*}{ C44 } & LaPP & 0.05 & 0.08 & 0.05 & 0.22 & 0.18 & 0.20 \\
\hline & LaOM & 0.03 & 0.05 & 0.03 & 0.14 & 0.11 & 0.12 \\
\hline \multirow[t]{3}{*}{ C46 } & LaPSt & 0.29 & 0.27 & 0.22 & 0.45 & 0.44 & 0.44 \\
\hline & LaOP & 0.24 & 0.22 & 0.18 & 0.32 & 0.33 & 0.32 \\
\hline & LaLP & 0.31 & 0.27 & 0.22 & 0.38 & 0.40 & 0.38 \\
\hline \multirow[t]{3}{*}{ C48 } & PPP & 0.50 & 0.51 & 0.39 & 0.92 & 0.86 & 0.88 \\
\hline & MOP & 0.29 & 0.25 & 0.21 & 0.38 & 0.39 & 0.38 \\
\hline & MLP & 0.08 & 0.14 & 0.09 & 0.37 & 0.29 & 0.33 \\
\hline \multirow[t]{3}{*}{ C50 } & PPSt & 1.75 & 1.72 & 1.35 & 2.96 & 2.82 & 2.85 \\
\hline & POP & 1.60 & 1.52 & 1.41 & 1.78 & 1.82 & 1.78 \\
\hline & PLP & 2.59 & 2.68 & 2.68 & 2.74 & 2.66 & 2.71 \\
\hline \multirow[t]{7}{*}{ C52 } & PStSt & 4.41 & 4.27 & 3.38 & 7.17 & 6.90 & 6.94 \\
\hline & POSt & 3.55 & 3.13 & 2.72 & 4.07 & 4.30 & 4.12 \\
\hline & POO & 2.01 & 2.17 & 2.39 & 1.60 & 1.54 & 1.60 \\
\hline & PLSt & 7.24 & 6.64 & 5.75 & 8.99 & 9.19 & 8.97 \\
\hline & PLO & 6.48 & 6.88 & 7.56 & 5.01 & 4.92 & 5.05 \\
\hline & PLL & 8.08 & 8.94 & 10.03 & 6.15 & 5.80 & 6.13 \\
\hline & PLnL & 0.71 & 1.09 & 1.42 & 0.36 & 0.14 & 0.31 \\
\hline \multirow[t]{11}{*}{ C54 } & StStSt & 4.21 & 4.01 & 3.19 & 6.55 & 6.39 & 6.38 \\
\hline & StOSt & 3.56 & 3.09 & 2.56 & 4.37 & 4.60 & 4.41 \\
\hline & StOO & 1.39 & 1.23 & 1.18 & 1.23 & 1.37 & 1.28 \\
\hline & StLSt & 8.54 & 7.55 & 6.20 & 11.05 & 11.41 & 11.04 \\
\hline & O०० & 0.74 & 1.14 & 1.49 & 0.38 & 0.15 & 0.32 \\
\hline & StLO & 7.18 & 6.19 & 5.74 & 6.64 & 7.40 & 6.92 \\
\hline & OLO & 4.91 & 5.80 & 6.92 & 2.92 & 2.57 & 2.90 \\
\hline & StLL & 7.80 & 6.34 & 5.40 & 7.94 & 8.94 & 8.26 \\
\hline & OLL & 9.10 & 9.98 & 11.38 & 6.18 & 5.95 & 6.25 \\
\hline & LLL & 9.76 & 10.95 & 12.56 & 6.77 & 6.33 & 6.78 \\
\hline & LLnL & 2.51 & 2.74 & 3.17 & 1.55 & 1.51 & 1.58 \\
\hline \multicolumn{8}{|c|}{ Majoritary Fatty acids (\%) } \\
\hline C16:0 & & 11.64 & 11.71 & 11.32 & 13.11 & 12.86 & 12.95 \\
\hline C18:0 & & 25.11 & 23.10 & 19.51 & 33.16 & 33.50 & 32.86 \\
\hline C18:1 & & 17.54 & 17.46 & 18.29 & 14.56 & 15.00 & 14.85 \\
\hline C18:2 & & 37.81 & 39.62 & 42.51 & 31.78 & 31.31 & 31.93 \\
\hline C18:3 & & 4.06 & 4.35 & 4.96 & 2.59 & 2.58 & 2.66 \\
\hline Other FA & & 3.85 & 3.76 & 3.41 & 4.80 & 4.75 & 4.75 \\
\hline
\end{tabular}

$\mathrm{La}=$ lauric acid, $\mathrm{M}=$ myristic acid, $\mathrm{P}=$ palmitic acid, $\mathrm{St}=$ stearic acid, $\mathrm{O}=$ oleic acid, $\mathrm{L}=$ linoleic acid, $\mathrm{Ln}=$ linolenic acid. $-:$ not detected. *Means of two measurements. 
Table 6 presents the total values of saturated, monounsaturated, polyunsaturated, and trans fatty acids in the commercial fats and their respective blends formulated by ANN with soybean-based fats. The ANN blends had higher polyunsaturated contents than the commercial fats. In addition, ANN blends $(1 \mathrm{~A}, 1 \mathrm{~B}$ and $1 \mathrm{C})$ formulated for commercial fat 1 had lower saturated contents, while the ANN blends (2A, 2B and 2C) formulated for commercial fat 2 had similar saturated contents.

The TAG composition of the commercial fats and the ANN formulations is presented in Table 6 according to the degree of saturation of the AG. The SSU and SUU TAG are the main components in the interesterified products, and the UUU TAG contained high values due to the presence of soybean oil in their formulations. The properties of fatty foods may be related to the TAG composition of the fat used in their formulation (O'Brien, 2004). SSS and SSU TAG are responsible for their structure, and SUU TAG are important due to their melting properties at body temperature and their plasticity at room temperature. The increase in SSU and SUU levels due to chemical interesterification is associated with increased functionality and improved sensory characteristics, which increases their application in foods (Ribeiro et al., 2009; Karabulut et al., 2004). Bornaz et al. (1993) evaluated TAGs and butter hardness and concluded that the SUU fraction decreases hardness, while SSS and SSU fractions increase butter hardness.

Figure 1 shows the consistency values (yield values) for the commercial fats and ANN formulations (commercial fat 1 and ANN formulations (a), commercial fat 2 and ANN formulations (b)). The commercial fat 1 was significantly different $(p>0.05)$ than the ANN formulations at all temperatures tested; however, the commercial fat 2 and the formulated ANN blends were similar at 10 and $20^{\circ} \mathrm{C}$. The commercial fat 2 and the respective formulated ANN blends had similar SSS TAG values, which may have played a role in their similar consistencies. In contrast, the commercial fat 1 and its respective ANN formulations showed greater differences in SSS and others TAG groups, as well as in their consistencies.

At the pilot plant scale, margarines with the commercial fat 1 and ANN blend $1 \mathrm{~A}$ were produced

Table 6

TAG composition and major fatty acids (FA) of the formulations proposed by the neural network

\begin{tabular}{ccccccccc}
\hline Samples & SFA & MFA & PFA & TFA & $\begin{array}{c}\text { SSS } \\
\text { TAGs }\end{array}$ & $\begin{array}{c}\text { SSU } \\
\text { TAGs }\end{array}$ & $\begin{array}{c}\text { SUU } \\
\text { TAGs }\end{array}$ & $\begin{array}{c}\text { UUU } \\
\text { TAGs }\end{array}$ \\
\hline Commercial fat 1 & 49.26 & 33.36 & 15.54 & 1.84 & 25.00 & 21.08 & 33.39 & 16.02 \\
1 A & 39.21 & 17.77 & 41.87 & 1.14 & 11.55 & 10.63 & 33.16 & 42.86 \\
1 B & 37.25 & 17.7 & 43.97 & 1.08 & 11.32 & 9.92 & 33.17 & 44.07 \\
1 C & 32.97 & 18.53 & 47.47 & 1.03 & 8.90 & 8.97 & 34.12 & 46.76 \\
Commercial fat 2 & 46.98 & 24.79 & 16.96 & 11.28 & 15,20 & 37.69 & 31.64 & 12.97 \\
3 A & 49.66 & 14.77 & 31.78 & 1.14 & 19.35 & 12.39 & 29.99 & 36.22 \\
3 B & 49.66 & 15.22 & 33.89 & 1.23 & 18.48 & 12.67 & 30.40 & 36.24 \\
3 C & 49.14 & 15.07 & 34.59 & 1.21 & 18.66 & 12.40 & 30.29 & 36.57 \\
\hline
\end{tabular}

SFA = Saturated Fatty acids; MFA = Monounsaturetd fatty acids; PFA = Polyunsaturated Fatty acids; TFA = Total trans Fatty acids; SSS = Trisaturated TAGs; SSU = Disaturated TAGs; SUU = Monosaturated TAGs; UUU = Triunsaturated TAGs
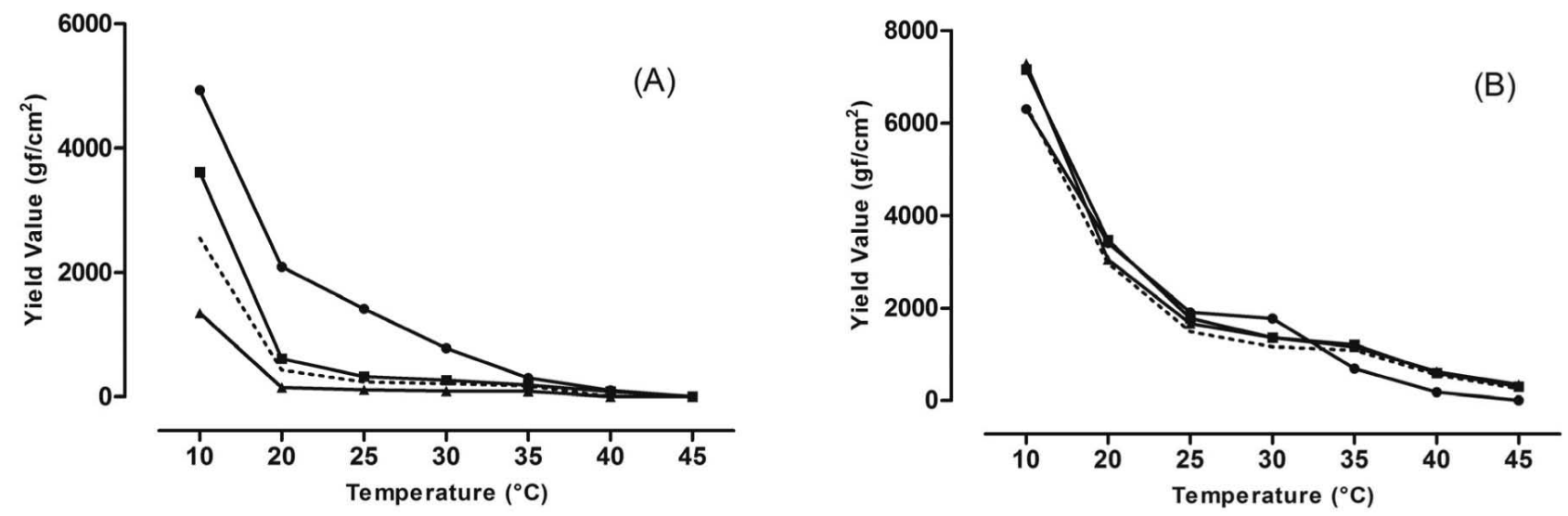

Figure 1

Consistency of commercial fats and formulated blends by ANN: Commercial Fat 1 (A) and Commercial Fat 2 (B). $\bullet$ Commercial fat 1 and 2; Formulation $1 \mathrm{~A}$ and $2 \mathrm{~A}$ proposed by $\mathrm{ANN}$; -- Formulation $1 \mathrm{~B}$ and $2 \mathrm{~B}$ proposed by $\mathrm{ANN}$; $\boldsymbol{\Delta}$ Formulation $1 \mathrm{C}$ and $2 \mathrm{C}$ proposed by ANN. 
to verify if it is possible to develop products with similar performance and characteristics despite the differences in raw materials. The consistency of the margarines was significantly different only at $10^{\circ} \mathrm{C}$ (Fig. 2A), which can be explained by the differences in the SFC and TAG. Figure 2 (B) shows the SFC of these two fatty bases.

According to pre-defined criteria, adequate margarine spreadability occurs at consistency values between 125 and $800 \mathrm{~g} \cdot \mathrm{cm}^{-2}$ (Haighton, 1959; Deman et al., 1989). The margarines produced (commercial fat and ANN formulation) had the expected consistencies for hard margarines. In addition, they had a desirable texture at room temperature, favoring melting at body temperature. Both margarines were spreadable at temperatures between 20 and $30^{\circ} \mathrm{C}$ according to sensory tests performed by experts. The margarine prepared with the formulation proposed by the ANN had a softer consistency, which may be an advantageous sensory characteristic, compared with the margarine produced with the commercial fat.

The margarine produced using the ANN formulation had an improved emulsion stability at the evaluated temperatures compared to the margarine prepared with the commercial fat. Margarine produced using the commercial fat had oil exudation at $35^{\circ} \mathrm{C}$, which increased over time. At the cooling temperature, both margarines had stable emulsions with no oil or water exudation. The higher stability of the margarine formulated by the ANN was attributed to the formation of a strong crystal lattice, which provided improved oil entrapment by the crystals and prevented the separation of the water/oil phase.

Despite some differences in the SFC and consistency between the commercial fat and ANN formulation, it was demonstrated that is possible to achieve the expected performance for hard margarines using soybean based interesterified fats. The margarine and the fat blends formulated by the
ANN with soybean-based fat resulted in improved nutritional characteristics, containing low saturated fats, zero trans fats, and high polyunsaturated fats.

\section{CONCLUSIONS}

The use of the soybean-based fats as raw materials is an alternative for the production of lowsaturated and low trans fat foods with lower costs in South American countries, especially in Brazil. Moreover, a specific ANN for the formulation of fats can be a very efficient tool for the development of formulations with profiles highly similar to those currently utilized in industry.

\section{ACKNOWLEDGMENTS}

The authors thank the Foundation for Research Support of São Paulo (FAPESP), the National Council for Scientific and Technological Development (CNPq), and the Coordination of Improvement of Higher Education Personnel (CAPES) for financial support.

\section{REFERENCES}

AOCS. 2004. Official Methods and Recommended Practices of the American Oil Chemists' Society, AOCS Press: Champaign, IL.

Antoniosi Filho N, Mendes OL, Lanças FM. 1995. Computer prediction of triacylglycerol composition of vegetable oils by HRGC. Chromatographia 40,557562.

Barrera-Arellano D, Block JM, Grimaldi R, Figueiredo MF, Gomide FC, Almeida RR. 2005. MIX - Software for formulation of fats with neural networks. Register INPI 98003155, Campinas, SP, Brazil.

Block JM, Barrera-Arellano D, Figueiredo M, Gomide FC. 1997. Blending process optimization into special fat formulation by neural networks. J. Am. Oil Chem. Soc. 74, 1537-1541.
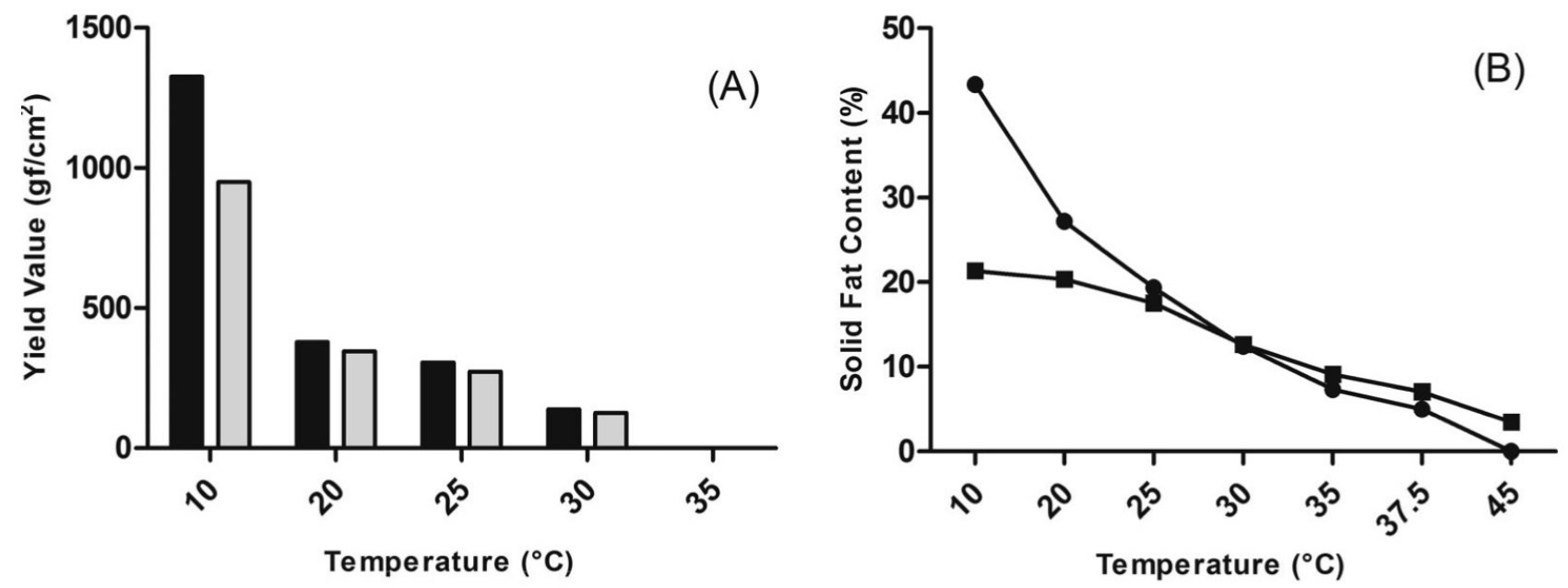

Figure 2

Consistency (yield value) of margarines produced at the pilot plant (A) and SFC of fats used in the production of the margarines (B). Black bar: Control margarine (commercial fat 1); Gray bar: Test margarine (Formulation $1 \mathrm{~A}$ by ANN); $\bullet$ Commercial fat 1;

- Formulation $1 \mathrm{~A}$. 
Block JM, Barrera-Arellano D, Figueiredo M, Gomide FC, Sauer L. 1999. Formulation of special fats by neural networks: A statistical approach. J. Am. Oil Chem. Soc. 76, 1357-1361.

Block JM, Barrera-Arellano D, Almeida R, Gomide FC, Moretti RB. 2003. Formulación de grasas através de redes neuronales: Productos comerciales y producción en planta piloto. Grasas Aceites 54, 240-244.

Bornaz S, Fanni J, Parmentier M. 1993. Butter texture: The prevalent triglycerides. J. Am. Oil Chem. Soc. 70, 1075-1079.

Brito LAL. 1994. Importancia de la instrumentación y computarización en programas de calidad total. Aceites Grasas 15, 99-102.

Deman L, Deman JM, Blackman B. 1989. Physical and textural evaluation of some shortening and margarines. J. Am. Oil Chem. Soc. 66, 128-131.

Gandra KM, Garcia RKA, Block JM, Barrera-Arellano D. 2009. Construction and training of a neural network for the formulation of specialty fats using interesterified fats. In: World Congress on Oils and Fats \& 28th ISF Congress - Oils and fats essential for life, Sydney, 117-118.

Haighton AJ. 1959. The measurement of the hardness of margarine and fat with con penetrometers. J. Am. Oil Chem. Soc. 36, 345-348.

Hartman L, Lago RCA. 1973. Rapid preparation of fatty acid methyl esters from lipids. Lab. Pract. 22, 475-476.

Hoffmam G. 1989. The chemistry and technology of edible oil and fats and their high fat products. Academic Press, London, 79-338.
Jeyarani T, Reddy SY. 2003. Preparation of plastic fats with zero trans FA from palm oil. J. Am. Oil Chem. Soc. 80, 1107-1113.

Karabulut I, Turan S, Ergin G . 2004. Effects of chemical interesterification on solid fat content and slip melting point of fat/oil blends. Food Res. Technol. 218, 224229.

Keys A, Anderson JT, Grande F. 1965. Serum cholesterol response to changes in the diet, IV. Particular saturated fatty acids in the diet. Metabolism. 14, 77687.

Mensink RP, Zock PL, Kester ADM, Katan MB. 2003. Effects of dietary fatty acids and carbohydrates on the ratio of serum total to $\mathrm{HDL}$ cholesterol and on serum lipids and apoproteins: a meta analysis of 60 controlled trials. Am. J. Clin. Nutr. 77, 1146-55.

O'Brien RD. 2004. Fats and Oils: Formulating and Processing for Applications. 2nd ed, CRC Press, New York.

Ribeiro APB, Grimaldi R, Gioielli LA, Gonçalves LAG. 2009. Zero trans fats from soybean oil and fully hydrogenated soybean oil: Physico-chemical properties and food applications. Food Res. Intern. 42, 401-410.

Ribeiro APB, Moura JMLN, Grimaldi R, Gonçalves LAG. 2007. Interesterificação química: Alternativa para obtenção de gorduras zero trans. Quim. Nova 30, 1295-1300. 